\title{
ATTRIBUTES TEMPTING STUDENTS' ONLINE PURCHASE INTENTION: THE MEDIATING ROLE OF PRE-PURCHASE SEARCHING
}

\author{
Ghazanfar Ali Abbasi ${ }^{*}$ \\ Al-Akhawayn University, Ifrane, Morocco \\ ghazanfar.abbasi@hotmail.co.uk \\ Jamshed Khalid \\ Universiti Sains Malaysia \\ jamshed.jt@gmail.com \\ Goh Yen Nee \\ Universiti Sains Malaysia \\ yngoh@usm.my \\ Nwakaji Christopher \\ Universiti Sains Malaysia \\ nwakajichristopher@gmail.com \\ Muhammad Khaleel \\ Universiti Sains Malaysia \\ Kshiry2000@gmail.com
}

\begin{abstract}
This study aims to examine the relationship between perceived usefulness (PU), perceived risk (PR) and online purchase intention (OPI). Furthermore, this study has endeavoured to elucidate the mediating role of pre-purchase searching (PS) between perceived risk (PR) and perceived usefulness (PU) and online purchase intention. This research is a correlational study conducted among students of Universiti Sains Malaysia to examine the purchase intention for online shopping. The variables are neither controlled nor manipulated. Data would be collected from the students in Universiti Sains Malaysia who are online purchase consumers. The results have supported the hypothesized direct and mediated relationship. The present study encompasses the body of knowledge through testing the Theory of Perceived Risk (TPR) and postulates empirical evidence on the hypothesized relationship. Moreover, this research study has contributed to the prevailing theory by assessing pre-purchase intention mediating by using partial least square structural modelling (PLS-SEM).
\end{abstract}

Keywords: Perceived Usefulness (PU), Perceived Risk (PR), Online Purchase Intention (OPI), Pre-Purchase Intention, and Theory Perceived Risk (TPR).

\section{INTRODUCTION}


The utilization of the Internet has intensely increased in recent years, subsequently providing people with more accessible means to gather information and engage in economic and social exchanges, social activities and online communities [1]. More than 4.2 billion people worldwide, constituting 55.1 per cent of the global population, have access to the Internet [2]. This soaring number of international users has created vast opportunities for doing online business. Moreover, the large-scale fruition of online shopping has attracted consumers and sellers all over the world. As a result, more and more people are engaged in electronic commerce (e-commerce). It has been projected that the global retail e-commerce will reach 4878 billion US dollars in 2020, an increase of 71 per cent from 2018 [3].

At this juncture, there is a need for research regarding potential factors driving online shopping intention [4,5], especially in developing countries such as Malaysia [6]. According to a Pricewaterhouse Coopers $(\mathrm{PwC})$ report, entitled the Total Retail Survey 2016, online shopping in Southeast Asian countries has displayed a significant increase from previous years than in developed countries [7]. Also, Malaysia is one of the advancing nations in terms of the Internet among developing countries. Consequently, it provides myriad opportunities for the online business market. Six out of ten people tend to purchase goods online in Malaysia, compared to the rest of the Asian countries. The availability of smartphones has further accentuated the online marketplace in the eyes of consumers. According to the latest statistics, Malaysia consists of 21.93 million internet users, representing 68.44 per cent of the whole population [8].

Furthermore, the online e-commerce market of Malaysia amounted to 3144 million US dollars in 2018. This value is expected to rise with an annual growth rate of 12.7 per cent, resulting in a 5719 million US dollars market volume by 2023 [9]. Furthermore, based on specific statistics revealed by the Malaysian Digital Association (2012), online shopping is ranked 11th among the top 15 reasons Malaysians gain access to the Internet [10]. Despite the dramatic increase in Internet users and the number of online purchases in recent years $[11,12,13]$, online shopping is still moving through its developmental stage in Malaysia [14]. The slow increase in consumer response towards online shopping is a surprise, triggering a significant concern among businesses, particularly online apparel shopping.

In this regard, a growing number of people are affected negatively by their purchases. According to a survey in 2013, it was discovered that around 71 per cent of people had regrets regarding their online purchases, whereas 48 per cent were dissatisfied due to their received products not meeting their expectations [15]. Aside from that, this survey revealed that 30 per cent of Malaysians failed to complete their online purchases since they preferred to research the products further and then decide whether to buy them or not in the end. Malaysian people are keen researchers before making purchases (as displayed in Table 1).

While a few research works have been carried out on consumers' online shopping intention, there is still an excessive need for empirical investigations on factors altering purchase intention in Malaysia. In an online environment, a good understanding of users' purchase intention can help web retailers develop appropriate strategies to attract current and prospective online customers [14]. Thus, this study examines factors that can influence customers' decisions to purchase online in Malaysia. 
Table 1: Five keen researchers nations before purchase

\begin{tabular}{ccc}
\hline Sr. & Country & \% of people \\
\hline 1 & Malaysia & 70 \\
\hline 2 & Taiwan & 69 \\
\hline 3 & Korea & 63 \\
\hline 4 & China & 59 \\
\hline 5 & Singapore & 54
\end{tabular}

Source: Self constructed from [19].

Furthermore, although many studies explore the divergent factors impacting the online shopping behaviour of students [16,17], extremely little research sheds light on pre-purchase searching. Developing how consumers conduct their search before purchasing is a critical component of marketing strategies [18]. Effective marketing communication at this stage can significantly influence consumers' decisions and bring extra revenue to a firm. Furthermore, Malaysia Communications and Multimedia Commission has narrated that out of the total Internet users in Malaysia, 62.5 per cent consists of university or college students due to widely available Wi-Fi connections in campuses [20]. Therefore, students get a lot of attention from marketers and retailers. For decades, with the recognition of the status of the pre-purchase search, various researchers have studied consumers' search for relative information before the purchase in a brick-and-mortar setting, only leaving a significant research gap in a rising online market. The process of the pre-purchase search for information is one of the most pivotal and multifaceted mechanisms in consumer decision-making [21].

Hence, the objective of this study is to provide a complete and realistic scenario of online shopping trends in Malaysia and, simultaneously, fill the literature gap. Moreover, in this research, researchers validate the factors affecting online purchase intention, particularly in Malaysia. Also, this study examines whether perceived risk and perceived usefulness affect student's online purchase intention or not. Finally, the mediating role of pre-purchase searching behaviour between perceived risk, usefulness, and online purchase intention is evaluated.

The following sections cover a review of the corresponding literature and the hypotheses. Also, the following section highlights the methodology employed by the researchers, and in the subsequent paragraphs, results are discussed and the study's conclusion.

\section{LITERATURE REVIEW}

\subsection{Technology Acceptance Model (TAM)}

The TAM is a modification of an already-existing theory known as the Theory of Reasoned Action (TRA). It was first proposed by Davis (1985), constituting perceived usefulness, perceived ease of use, attitude and the intention to use a kind of technology [22-24]. Both perceived ease of use and usefulness have been significant drivers of users' intention to use a system [25]. Moreover, the TAM has been successfully applied in a plethora of literature regarding information systems [26, 27]. This illustrates that increased perceived usefulness enhances usage, as it upsurges the user's performance in accomplishing tasks - consequently, the individual gains more motivation to practice it. Hence, the intention to use in consumers becomes significantly higher. 
The Technology Acceptance Model is widely interpreted as an attitude regarding technology intention by mentioning perceived usefulness. The TAM can also be applied in customer purchase intention towards online shopping and satisfaction [28, 29]. However, despite being a well-established, powerful and robust model, the TAM is still considered incomplete [30] because it excludes economic, demographic and external factors [31]. Therefore, extant studies have suggested supplementing the TAM with additional variables to understand better and predict technology usage behaviour [32]. Earlier studies [33] have ascertained that the prime factors of TAM (i.e. PU and PEOU) have proven to be the most constructive elements in predicting acceptance of information systems in various settings, namely online shopping and shopping using mobile phones [34].

\subsection{Online Purchase Intention}

The emergence of electronic commerce (e-commerce) has made the online shopping channel the third most happening activity on the Internet, after email sending and online browsing [35]. With the unprecedented rise of e-commerce, the idea of purchase intention has been stretched to online environments [36]. According to the existing literature in this regard, online purchase intention can be defined as the willingness of consumers to utilize online technology in order to purchase products and services [37]. Similarly, consumer readiness to buy from the Internet platform is also defined as the online purchase intention [38]. Furthermore, one research work has described online purchase intention as consumers' disposition to make an actual purchase or compare the prices of various products and services using the Internet [39]. Therefore, consumers' intention to purchase is regarded as one of the main drivers of actual behaviour.

In the virtual world, consumer purchase intention is deemed crucial and a prerequisite for measuring their overall behaviour, which is highly influenced by various ever-changing factors [40]. Also, consumers' intention to act is regarded as a psychological behaviour and is, therefore, linked to consumers' cognition which ultimately impacts their decision to buy a product or not [41]. Aside from that, consumers' anticipation of the perceived usefulness of new technologies affects their work performance. Consumer's purchase intention is a vital factor in determining their online shopping behaviour. As a result, it is essential to comprehend how Internet consumers evaluate and compare several potential products by adopting pre-purchase search behaviour before deciding which products to purchase online. Hence, consumers' purchase intention is treated as a dependent variable in this study.

\subsection{Perceived Usefulness}

Perceived usefulness elucidates that people are willing to improve online transaction efficiency regarding specific tasks via the utilization of e-commerce [42]. It has also been defined as the extent to which a person believes that using a particular technology will enhance their job performance. In this regard, when students, as customers, do online shopping, they need to enjoy the convenience of searching for the product's image and price, comments from other buyers, tracking the related logistics and evaluating the corresponding services [43]. Similarly, another study has been conducted to determine the internal factors affecting online consumers' search for information, empirically concluding that perceived usefulness plays a significant role 
in consumers' behaviour regarding the search for product information [44]. Therefore, perceived usefulness is one of the most essential considerations when customers compare online shopping with traditional shopping [45]. Thus, this leads to the following hypothesis:

H1: Perceived usefulness is positively related to pre-purchase searching.

\subsection{Theory of Perceived Risk (TPR)}

Since the 1960s, researchers have used the Theory of Perceived Risk to explain consumers' behaviour. Information searching is a common method implemented by consumers to reduce perceived risks [46]. Thus, perceived risks can be considered a function of uncertainty about the potential outcomes of behaviour and the possible unpleasantness of these outcomes [47], representing consumer uncertainty about loss or gain in a particular transaction. Perceived risk is defined as an attribute of an alternative decision reflecting the variance of its possible outcomes [48]. Consumers perceive Internet shopping to have a higher risk, as compared to in-store shopping [49].

As stated by another study, in web-based businesses, it is pivotal to decrease the perception of risks that subsequently reduces consumers' intention to repurchase [50]. Similarly, it is declared that perceived risks have a negative impact on customers' online purchase intention [51]. Likewise, researchers conducted a study on the Malaysian people regarding boiler chicken and discovered that perceived risks significantly impact the behavioural intention of consumers. Moreover, it is indicated that perceived risks related to online purchase intention are likely to be affected by customers' experience and perspectives [53]. Perceived risks have been determined as a predictor of consumers' behaviours on the subject of online purchasing [54]. For instance, it is discovered that perceived risks are significantly related to the amount and frequency of online purchases among consumers of New Zealand [55]. In addition, based on the results of another research, consumers' perceived risks regarding online shopping are negatively related to the extent to which college students subscribe to online services and purchased products via the Internet [56].

Furthermore, risks may appear in a shopping environment when a consumer believes that he cannot control the outcome or the consequences of his decisions [57, 58]. According to a study [59], consumers who are not willing to purchase online can be attributed to risk perception regarding the product quality, payment method, content of information and delivery options. In the online shopping world, due to the fact that one is more uncertain about the quality of products and it becomes difficult to evaluate effects online, compared to the products one has already searched for, higher levels of perceived risks are often associated with consumers [60]. Moreover, customers with no aptitude to testify or compare the quality of products feel more risks in online purchasing [61]. Perceived risks can be considered as key barriers to relishing the advantages of online purchasing [62]. However, search for information is an effective means of risk reduction, and higher perceived risks lead to more search [63, 64]. Therefore, the above discussion has led to the making of the following hypothesis:

$\mathrm{H} 2$ : Perceived risk is negatively related to pre-purchase searching.

\subsection{Pre-purchasing Searching and Its Mediating Effect}


In the current day and age, the Internet and electronic market has evolved, and flocks of people are now making online purchases and seeking more relevant products or services online [60]. As stated by one work of research [64], searching refers to the efforts made by the consumer about the product or services before making a purchase online. Similarly, another study [66] proposed that customers pay more attention to four factors: website introduction, product lists, product advertisement, and product information. Furthermore, they evaluate their intention of online purchasing through pre-purchase searching in order to overcome the element of risk, uncertainty and incredibility of the product [51]. Seeking a product's information is considered pivotal in the early steps of a consumer's buying process [67]. An investigation [65] regarding consumers' purchase intention concluded that consumers spend a reasonable amount of time, in fact much more, on the internet search and comparing information regarding several products and services. According to another study [68], 81 per cent of American people engage in online pre-purchase searching.

Moreover, satisfactory consumers like to share their online search experience and advise their friends when they consult them about the risks of online purchasing [69]. The effective usefulness of the pre-purchase searching behaviour through friends or relatives decreases risks associated with online buying. It may also aid them in making a successful online purchase transaction. In the extant literature, there are two types of search intention: goal-directed search and expletory search. Goal-oriented consumers search for efficient information, whereas those who do expletory search do not have any specific targets [70]. Research has proven that search-related behaviour positively affects the intention to shop online [70,71]. It has also been stated that the nature of search in brick-and-mortar stores is significantly different compared to click and mortar. The Internet has overcome the limitation of time and space and provides a convenient medium to search [71]. Research has proven a positive relationship between prepurchase search and online purchase intention $[60,70,71]$. Therefore, this discussion has led to the formulation of the following hypothesis:

H3: Pre-purchase searching is positively related to purchase intention.

H4: The relationship between perceived risks and purchase intention is less when the purchase-related search is high.

H5: The relationship between perceived usefulness and purchase intention is greater when the amount of purchase-related searching is high.

To sum up, towards a deeper understanding of purchase intention in students, this research aims to propose a theoretical model (Figure 1) that expands the TAM by four constructs: perceived risks, pre-purchase searching, perceived usefulness and online purchase intention. The theoretical framework of this study is developed to examine the factors fluctuating the purchase intention of students in Universiti Sains Malaysia (USM), Malaysia. 


\section{Theoretical Framework}

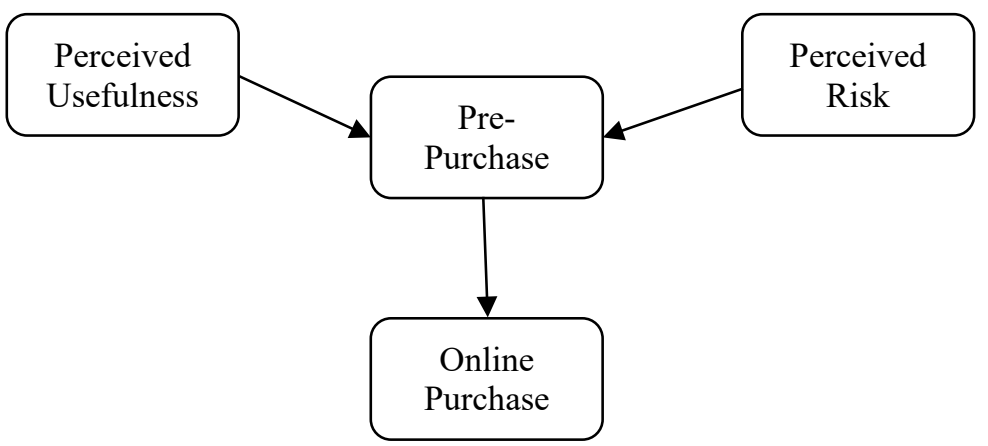

Figure 1. The theoretical framework for online purchase intention

\section{RESEARCH METHODOLOGY}

\subsection{Measurements}

The constructs used in this study were adopted from the existing literature and modified to meet the study's objectives. All items were measured using a seven-point Likert scale that ranged from (1) strongly disagree to (7) strongly agree, except for online purchase intention, which was measured using a five-point Likert scale ranging from (1) strongly disagree to (5) strongly agree. The choice of adopting different scales was made based on the suggestions of a study [72] to reduce the common method bias. Table 2 defines and summarizes the measures of the nine constructs used in this study.

\subsection{Data Collection \& Sample}

This study adopted a structured questionnaire to collect data for each variable. In this regard, convenience sampling was used, and the respondents were invited to participate in the survey voluntarily. This research is a correlational study conducted among students of Universiti Sains Malaysia to examine their purchase intention on the subject of online shopping. For this reason, surveys were distributed among students who were enrolled in USM and had experience in online shopping. A self-administered method in the form of drop-off surveys was used to ensure participant confidentiality.

Moreover, the survey was distributed among participants in their classrooms where they could anonymously return their responses into a provided collection box immediately upon completion, which would have taken 10 to 15 minutes of their time. This survey comprised two filtering questions, demographic information, intention to purchase, pre-purchase searching, perceived usability and perceived risks involved in online shopping. Around 300 questionnaires were distributed, and 259 were returned to the researchers (response rate of 86.33 per cent). All the returned questionnaires were thoroughly scrutinized, and 13 responses out of 259 were discarded, leaving 246 questionnaires deemed fit for data analysis. 
Table 2: The Measures and Layout of the Questionnaire.

\begin{tabular}{|c|c|c|c|c|}
\hline Section & Variable & Definitions & Items & Source \\
\hline & $\begin{array}{c}\text { Demographics } \\
\text { Details }\end{array}$ & & 7 & Self-Constructed \\
\hline A & $\begin{array}{l}\text { Perceived } \\
\text { Usefulness } \\
\text { (PU1-PU4) }\end{array}$ & $\begin{array}{l}\text { The extent to which a } \\
\text { person believes that using } \\
\text { a particular technology } \\
\text { will enhance his/her job } \\
\text { performance. }\end{array}$ & 4 & [42] \\
\hline B & $\begin{array}{l}\text { Perceived } \\
\text { Risk } \\
\text { (PR1-PR4) }\end{array}$ & $\begin{array}{l}\text { The degree of one's } \\
\text { negative feelings about } \\
\text { risk when customers } \\
\text { choose online purchase. }\end{array}$ & 4 & {$[51]$} \\
\hline $\mathrm{C}$ & $\begin{array}{l}\text { Purchase } \\
\text { Intention } \\
\text { (PI1-PI3) }\end{array}$ & $\begin{array}{l}\text { The degree to which one } \\
\text { believes that customers } \\
\text { have the intention to do an } \\
\text { online purchase. }\end{array}$ & 3 & {$[28]$} \\
\hline $\mathrm{D}$ & $\begin{array}{l}\text { Pre-purchase } \\
\text { Searching } \\
\text { (PPS1-PPS5). }\end{array}$ & $\begin{array}{l}\text { The degree to which one } \\
\text { is eager to search product } \\
\text { information before they } \\
\text { purchase online. }\end{array}$ & 5 & {$[70]$} \\
\hline
\end{tabular}

\subsection{Respondents}

All 246 respondents fulfilled the filtering criteria of the study, i.e. being students and having an online shopping experience. The demographics of the respondents are tabulated in Table 3. In this regard, the number of females (57.7 per cent) respondents was slightly larger than that of male respondents ( 42.27 per cent). The majority of the respondents fell in the age group of 26 to 30 years (42.1 per cent). Also, most of the respondents in this study were degree holders ( 86 per cent). This is due to the recruitment requirements set by the hiring authorities. As discussed, earlier data was collected from the students of Universiti Sains Malaysia, and about 79 per cent of them were undergraduate students. Furthermore, the majority of the respondents were single (88.6 per cent). Lastly, almost half of the respondents were in the age range of 21 to 29.

\section{RESULTS}

The Partial Least Squares (PLS) technique was used to test the proposed relationships in this study. The PLS technique is selected due to the exploratory nature of the study [73]. Following the recommendation of a specific study [73], the model of the study was tested in two steps. In the first step, the measurement model was evaluated to establish the validity and reliability of the questionnaire. After that, in the second step, the study's hypotheses were tested using the bootstrapping technique.

\subsection{Measurement Model}

The study utilized the Structural Equation Model (SEM) and the PLS approach and applied the SmartPLS (version 3.2.6) data analysis tool for model estimation and multivariate analysis. To test the validity and reliability of the measurement model, 
specific criteria such as the outer loadings, composite reliability (CR), Average Variance Extracted (AVE) and Heterotrait-Monotrait (HTMT) were evaluated. According to the results, the outer loadings of all items and the CR and AVE of all constructs were above $0.7,0.7$, and 0.5 , respectively. Thus, meeting the rule of thumb stated by the study as mentioned earlier [73], thus establishing convergent validity.

However, during measurement model evaluation, PPS3 factor loading was low and affected the construct's AVE. As per Hair et al. (2016), Hair et al. (2011), and Bagozzi et al. (1991) instructions, any factor loading which is below 0.40 should, however, be eliminated from the construct. The outer loading of PPS3 was coming to 0.343, which was lower than the prescribed figure, therefore, removing PPS3 increased the average variance extracted (AVE) of the construct PPS.

Table 3: Respondents Profile

\begin{tabular}{ccc}
\hline Demographic Data & Frequencies $\mathrm{n}=246$ & Percentage \\
\hline Gender & & \\
Female & 142 & 57.7 \\
Male & 104 & 42.3 \\
Age & & \\
21 and Less & 86 & 35 \\
$22-25$ & 92 & 37.4 \\
$25-28$ & 47 & 19.1 \\
29 and above & 21 & 8.5 \\
Education & & 79 \\
Undergraduate & 194 & 14.6 \\
Master & 36 & 6.5 \\
Postgraduate & 16 & 88.6 \\
Marital Status & & 11.4 \\
Single & 218 & \\
Married & 28 &
\end{tabular}

Table 4: Measurement Model

\begin{tabular}{|c|c|c|c|c|}
\hline Measurement & Loadings & Cronbach Alpha & Composite Reliability & AVE \\
\hline PI1 & 0.789 & 0.63 & 0.801 & 0.576 \\
\hline PI2 & 0.837 & & & \\
\hline $\mathrm{PI} 3$ & 0.636 & & & \\
\hline PPS1 & 0.852 & 0.754 & 0.837 & 0.572 \\
\hline PPS2 & 0.905 & & & \\
\hline PPS4 & 0.541 & & & \\
\hline PPS5 & 0.672 & & & \\
\hline PU1 & 0.84 & 0.885 & 0.864 & 0.618 \\
\hline PU2 & 0.882 & & & \\
\hline PU3 & 0.859 & & & \\
\hline PU4 & 0.868 & & & \\
\hline PR1 & 0.695 & 0.849 & 0.921 & 0.743 \\
\hline PR2 & 0.933 & & & \\
\hline PR3 & 0.626 & & & \\
\hline PR4 & 0.853 & & & \\
\hline
\end{tabular}




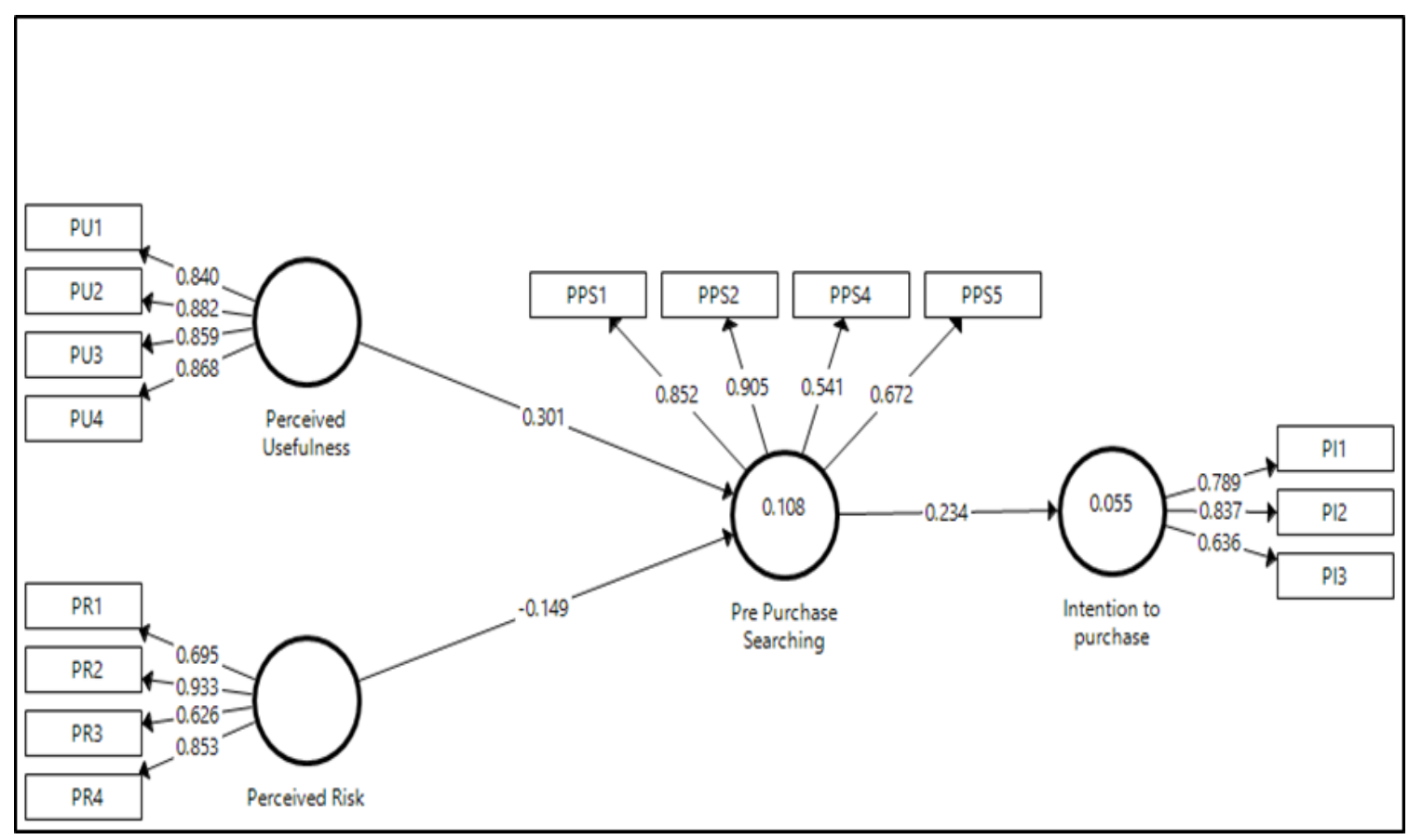

Figure 2: Measurement Model

To establish the discriminant validity, the Heterotrait-Monotrait (HTMT) criteria were employed in this study [74]. In total, the measurement model demonstrated adequate convergent validity and discriminant validity.

The HTMT ratios were consistently lower than the most restrictive threshold of 0.85 [75], indicating satisfactory discriminant validity properties. Therefore, the measurement model results suggest that the validity and reliability criteria were met and that constructs developed for this measurement model were helpful in testing the structural model and associated hypotheses.

Table 5: Hetrotrait-Monotrait Ratio (HTMT)

\begin{tabular}{rlcccc}
\hline No & Variable & $\begin{array}{c}\text { Intention to } \\
\text { purchase }\end{array}$ & $\begin{array}{c}\text { Perceived } \\
\text { Risk }\end{array}$ & $\begin{array}{c}\text { Perceived } \\
\text { Usefulness }\end{array}$ & $\begin{array}{c}\text { Pre-purchase } \\
\text { Searching }\end{array}$ \\
\hline 1 & $\begin{array}{l}\text { Intention } \\
\text { purchase } \\
\text { Perceived }\end{array}$ & 0.091 & & & \\
2 & $\begin{array}{l}\text { Risk } \\
\text { Perceived }\end{array}$ & 0.743 & 0.072 & & \\
3 & $\begin{array}{l}\text { Usefulness } \\
\text { Pre-purchase } \\
\text { Searching }\end{array}$ & 0.303 & 0.107 & 0.324 & \\
\hline
\end{tabular}

\subsection{Structural Model Evaluation}

In examining the structural model, $\mathrm{R}^{2}$, beta and the corresponding t-values are involved [76]. To obtain the t-values, a bootstrapping process with 500 resamples was applied. T-values are considerably important in accepting or rejecting a hypothesis. 
First, one must consider the predictors of pre-purchase searching. Perceived usefulness $(\beta=0.301, p<0.01)$ is positively related to pre-purchase searching, explaining 5 per cent (weak) of variance regarding pre-purchase searching by the predictor variables. Hence, H1 is supported. Perceived Risk $(\beta=-0.149, \mathrm{p}>0.05)$ is negatively related to pre-purchase searching. Consequently, $\mathrm{H} 2$ is also supported. Secondly, one needs to observe the relationship between pre-purchase searching and the intention to purchase. $\mathrm{H} 3$ is supported in this study, illustrating a positive relationship between pre-purchase searching $(\beta=0.234, \mathrm{p}<0.01)$ and the intention to purchase. This explains 10.8 per cent (weak) of variance concerning the intention to purchase.

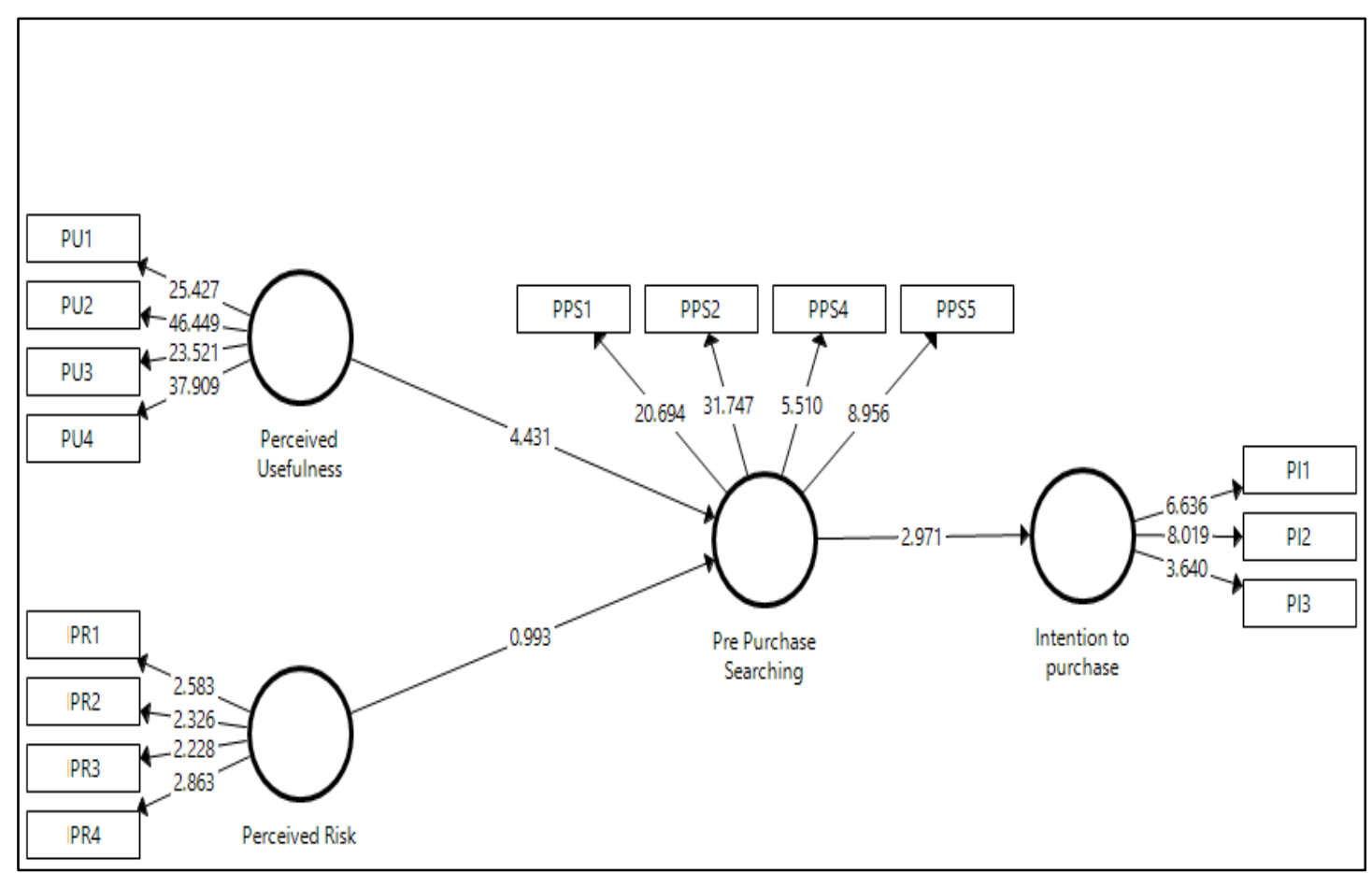

Figure 3: Structural model

Table 6: Direct Effect

\begin{tabular}{cccccc}
\hline & Path & Beta & $\begin{array}{c}\text { Standard } \\
\text { Error }\end{array}$ & T Value & P Values \\
\hline H1 & $\begin{array}{c}\text { Perceived Risk } \\
\text { - > Pre-purchase Searching } \\
\text { Perceived Usefulness } \\
\text { - }>\text { Pre-purchase Searching }\end{array}$ & $\begin{array}{c}0.149 \\
\text { H2 }\end{array}$ & 0.15 & 0.993 & 0.321 \\
H3 & $\begin{array}{c}\text { Pre-purchase Searching } \\
\text {-> Intention to purchase }\end{array}$ & 0.234 & 0.068 & 4.431 & 0 \\
\hline
\end{tabular}

Testing the mediating effect of pre-purchase searching is another objective of this study. This section explains the mediating impact of pre-purchase searching in the relationship between perceived risks and the intention to purchase and the relationship between perceived usefulness and the intention to purchase. In this concern, a study's estimation $[77,78]$ of the mediation effect for SEM with the bootstrap test was used, as it is considered more suitable than another research's concept $[79,80]$ of mediation. 
The former study $[77,78,81]$ exposed that the mediation effect is considered significant while the indirect effect between independent and dependent variables possesses more significance. In this study, the indirectimpact of pre-purchase searching was insignificant between the relationship between perceived risks and the intention to purchase and significant in the relationship between perceived usefulness and the intention to buy. Therefore, Hypotheses 4 and 5 are found to be unsupported and supported, respectively. The results of the mediation effect are displayed in Table 7.

Table 7: Indirect Effect

\begin{tabular}{|c|c|c|c|c|c|}
\hline & Path & Beta & $\begin{array}{l}\text { Standard } \\
\text { Error }\end{array}$ & T Value & $\begin{array}{c}\mathrm{P} \\
\text { Values }\end{array}$ \\
\hline & Perceived Risk & & & & \\
\hline $\mathrm{H} 4$ & $\begin{array}{c}->\text { Pre-purchase Searching } \\
\text {-> Intention to purchase }\end{array}$ & -0.035 & 0.041 & 0.856 & 0.392 \\
\hline H5 & $\begin{array}{l}\text { Perceived Usefulness } \\
\text {-> Pre-purchase Searching } \\
\text {-> Intention to purchase }\end{array}$ & 0.07 & 0.039 & 1.793 & 0.05 \\
\hline
\end{tabular}

\section{DISCUSSION}

This study investigates the role of perceived usefulness, perceived risks, and online purchase intention among university students in Penang. Furthermore, this research has endeavoured to elucidate the mediating role of pre-purchase searching between perceived risks and usefulness. Perceived usefulness has shown a positive relationship with the intention regarding pre-purchase searching. This indicates that consumers in this age, particularly young people, put great emphasis on pre-purchase searching, especially when it comes to buying products or services online. Moreover, this study's descriptive statistics highlight that women are keener on searching or browsing for information prior to purchasing online. This confirms that young consumers, specifically students, realize the importance of the usefulness of pre-purchase before committing to purchase online.

Furthermore, perceived risks in this regard have shown a negative relationship with pre-purchase searching in electronic commerce. This result is consistent with previous extant literature [57, 58, 81]. It is suggested that consumers, especially younger generations, are more sceptical about the risks involved in any online activity. The element of risk in e-commerce proves to handicap the augmentation of the online buying culture $[62,81]$. However, searching for information, especially prior to any online purchase, caters to the negative feelings aroused by risks. Moreover, the more the presence of risks becomes, the more consumers engage themselves in pre-purchase searching.

Similarly, pre-purchase searching has demonstrated both significant and insignificant relationships between perceived usefulness and perceived risks and online purchase intention. This highlights that younger consumers, i.e. students rely heavily on the usefulness of pre-purchase searching in augmenting the online purchase behaviour. At the same time, the empirical results of this study also display unpredictable results stating that pre-purchase does not play a significant role in eliminating risks when making a purchase online. These findings are inconsistent with the results of related studies [65 and 66] that indicate that customers assess their buying 
intentions through pre-purchase searching to overcome the element of risk, uncertainty and incredibility of the products [51].

\section{THEORETICAL AND PRACTICAL IMPLICATIONS}

From the theoretical perspective, this research extends the related literature regarding online shopping intentions by illustrating the factors that can enhance and highlight the importance of pre-purchase searching behaviour, especially in the everchanging online buying world. The findings show that both perceived risks and perceived usefulness play a significant role in pre-purchase behaviour in consumers' decision-making regarding online buying.

Moreover, from the practical perspective, the findings of this study can be helpful to policymakers and help them determine factors that motivate the online searching behaviour of consumers, which subsequently impacts online buying. These results also allow e-retailers to develop policies effectively in order to promote online buying behaviour. This can influence their success which, later on, reflects in growth in the country's economy.

\section{LIMITATIONS AND FUTURE STUDIES}

Although this study has achieved its objectives, it has some limitations that can be considered for future studies. Firstly, the proposed theoretical model in this research does not include all potential variables applicable to online purchase intention, namely past experiences and word of mouth, attitude and perceived ease of use in examining consumers' buying behaviours, as suggested by Abbasi et al. [82] and Iranmanesh et al. [90] that the use of consumer emotion such the element of regret can be swayed to stimulate their buying behaviour. Secondly, the study is cross-sectional, limiting the ability to observe dynamic changes in consumers' behaviours. As such, the proposed relationships should be examined for an extended period of time in order to provide more accurate results. Thirdly, the data was collected from students of only one university, i.e. Universiti Sains Malaysia, and the determinants of the online buying intention of consumers may be different in other communities in Malaysia. In this regard, future studies can test the same model by applying experimental or longitudinal approaches.

\section{REFERENCES}

[1] Lissitsa, S., \& Kol, O, "Generation X vs. Generation Y-A decade of online shopping," Journal of Retailing and Consumer Services, Vol. 31, 304-312, 2016.

[2] InternetWorldStats. (2018). World Internet Users and 2016 Population Stats[Online]. Available: http://www.internetworldstats.com/stats.htm

[3] Statista. (2019, Mar. 2 ). Retail e-commerce sales worldwide from 2014 to 2021[Online]. Available: https://www.statista.com/statistics/379046/worldwideretail-e-commerce-sales/

[4] Hasan, B. "Perceived irritation in online shopping: The impact of website design characteristics," Computers in Human Behavior, Vol. 54, pp. 224-230, 2016.

[5]. Akhlaq, A., and E. Ahmed, "Digital commerce in emerging economies: factors associ- ated with online shopping intentions in Pakistan," International Journal of Emerging Markets, Vol. 10, No. 4, pp. 634-47, 2015. 
[6] Lim, Y. J., Osman, A., Salahuddin, S. N., Romle, A. R., \& Abdullah, S, "Factors influencing online shopping behavior: the mediating role of purchase intention. Procedia Economics and Finance," Vol. 35, pp. 401-410, 2016.

[7] Pricewaterhouse Coopers. They say they want a revolution: Total retail 2016[Online].Available:https://www.pwc.com/gx/en/retailconsumer/publications /assets/total-retail-global-report.pdf

[8] Statista. (2018, Feb. 23). Number of internet users in Malaysia from 2017 to 2023[Online]. Available: https://www.statista.com/statistics/553752/number-ofinternet-users-in-malaysia/

[9] Statista. (2018). eCommerce, Malaysia. Retrieved 22nd January 2019[Online]. Available: https:/www.statista.com/outlook/243/122/ecommerce/malaysia

[10] Malaysia Digital Association. (2012). Malaysia Website Ranking for February 2012, Retrieved on 10 Nov, 2016. Retrieved Nov 10, 2016[Online]. Available: http://www.digital.org.my/pdf/MDA-EM

[11] Daliri, E., Rezaei, S., \& Ismail, W. K. W. "Online social shopping: the impact of attitude, customer information quality, effectiveness of information content and perceived social presence," International Journal of Business Environment, Vol. 6, No. 4, pp. 426-450, 2014.

[12] Rezaei, S., "Segmenting consumer decision-making styles (CDMS) toward marketing practice: A partial least squares (PLS) path modeling approach," Journal of Retailing and Consumer Services, Vol. 22, pp. 1-15, 2015.

[13] Rezaei, S., Amin, M., \& Khairuzzaman Wan Ismail, W., "Online repatronage intention: an empirical study among Malaysian experienced online shoppers," International Journal of Retail \& Distribution Management, Vol. 42, No. 5, pp. 390-421, 2014.

[14] Ling, K. C., Chai, L. T., \& Piew, T. H., "The effects of shopping orientations, online trust and prior online purchase experience toward customers' online purchase intention," International Business Research, Vol. 3, No. 3, pp. 63, 2010.

[15]Rakuten. (2013). Malaysians Tend to Regret Online Purchases. Retrieved Nov 12, 2016[Online]. Available: http://www.maxit.my/2013/10/malaysians-tend-toregret-online-purchases/

[16]de Faultrier, B., Boulay, J., Feenstra, F., \& Muzellec, L., "Defining a retailer's channel strategy applied to young consumers," International Journal of Retail \& Distribution Management, Vol. 42, No.11/12, pp. 953-973, 2014.

[17] McNamee, S., \& Seymour, J., "Towards a sociology of 10-12 year olds? Emerging methodological issues in the "new'social studies of childhood," Childhood, Vol. 20, No. 2, pp.156-168, 2013.

[18] Moorthy, S., Ratchford, B. T., \& Talukdar, D. Consumer information search revisited: Theory and empirical analysis. Journal of consumer research, Vol.23, No.4, pp. 263-277, 1997.

[19] eCommercemilo. (2015). Malaysian online shopping trend. Retrieved 11 Nov, 2016[Online]. Available: http://www.ecommercemilo.com/2015/01/malaysianonline-shopping-trend.html

[20] Yeap, J. A., Ramayah, T., \& Soto-Acosta, PP., "Factors propelling the adoption of m-learning among students in higher education," Electronic Markets, Vol. 26, No. 4, pp. 323-338, 2016.

[21] Gursoy, D., "A critical review of determinants of information search behavior and utilization of online reviews in decision making process (invited paper for 'luminaries' special issue of international journal of hospitality management)," International Journal of Hospitality Management, Vol. 76, pp. 53-60, 2019. 
[22] Davis, F. D., "Perceived usefulness, perceived ease of use, and user acceptance of information technology," MIS quarterly, pp. 319-340, 1989.

[23] Hernández, B., Jiménez, J., \& Martín, M. J., "Customer behavior in electronic commerce: The moderating effect of e-purchasing experience," Journal of business research, Vol. 63, No. 9-10, pp. 964-971, 2010.

[24] Hsu, Y. H., Li, C. K., Li, C. M., \& Liu, N. T., "The effect of website quality features and cognitive absorption on social network site usage: A cross-national study," International Journal of Electronic Commerce Studies, Vol. 7, No. 2, pp. 156-188, 2016.

[25] Siyal, A. W., Donghong, D., Umrani, W. A., Siyal, S., \& Bhand, S., "Predicting mobile banking acceptance and loyalty in chinese bank customers," SAGE Open, Vol. 9, No. 2, pp. 1-21, 2019.

[26] Pelaez, A., Chen, C. W., \& Chen, Y. X. Effects of perceived risk on intention to purchase: a meta-analysis. Journal of computer information systems, Vol. 59, No. 1, pp. 73-84, 2019.

[27] Kim, H., \& Song, J. The quality of word-of-mouth in the online shopping mall. Journal of Research in Interactive Marketing, Vol. 4, No. 4, pp. 376-390, 2010.

[28]Chin, S. L., \& Goh, Y. N. Consumer purchase intention toward online grocery shopping: view from Malaysia. Global Business and Management Research, Vol. 9, No. 4s, pp. 221-238, 2017.

[29] Khare, A., \& Sadachar, A. Collective self-esteem and online shopping attitudes among college students: Comparison between the US and India. Journal of International Consumer Marketing, Vol. 26, No. 2, pp. 106-121, 2014.

[30] Brown, S. A., \& Venkatesh, V. Model of adoption of technology in households: A baseline model test and extension incorporating household life cycle. MIS quarterly, Vol. 29, No. 3, 2005

[31] Mehrad, D., \& Mohammadi, S. Word of Mouth impact on the adoption of mobile banking in Iran. Telematics and Informatics, Vol. 34, No. 7, pp. 1351-1363, 2017

[32] Liébana-Cabanillas, F., Marinković, V., \& Kalinić, Z. A SEM-neural network approach for predicting antecedents of m-commerce acceptance. International Journal of Information Management, Vol. 37, No. 2, pp. 14-24, 2017

[33]Venkatesh, V., \& Davis, F. D. A theoretical extension of the technology acceptance model: Four longitudinal field studies. Management science, Vol. 46, No. 2, pp. 186-204, 2000

[34] Chen, Y. M., Hsu, T. H., \& Lu, Y. J. Impact of flow on mobile shopping intention. Journal of Retailing and Consumer Services, Vol. 41, pp. 281-287, 2018

[35] Jamali, S.K., Samadi, B. and Marthandan, G. (), "Prioritizing electronic commerce technologies in Iranian family SMEs", Interdisciplinary Journal of Contemporary Research in Business, Vol. 6, No. 2, ppp. 148-180, 2014

[36] Teng, H. J., Ni, J. J., \& Chen, H. H. Relationship between e-servicescape and purchase intention among heavy and light internet users. Internet Research, Vol. 28, No. 2, pp. 333-350, 2018

[37] Ha, H. Y., \& Janda, S. The effect of customized information on online purchase intentions. Internet Research, Vol. 24, No. 4, pp. 496-519, 2014

[38] Meskaran, F., Ismail, Z. and Shanmugam, B., "Online purchase intention: effects of trust and security perception", Australian Journal of Basic and Applied Sciences, Vol. 7, No. 6, ppp. 307-315, 2013

[39] Iqbal, S., Rehman, K. and Hunjra, A.I., "Consumer intention to shop online: B2C e-commerce in developing countries", Middle East Journal of Scientific Research, Vol. 12, No. 4, 2012 
[40] Kamalul Ariffin, S., Mohan, T., \& Goh, Y. N., "Influence of consumers' perceived risk on consumers' online purchase intention", Journal of Research in Interactive Marketing, Vol. 12, No. 3, pp. 309-327, 2018

[41] Yong, N. L., Ariffin, S. K., Nee, G. Y., \& Wahid, N. A., "A study of factors influencing consumer's purchase intention toward green vehicles: evidence from malaysia", Global Business and Management Research, Vol. 9, No. 4, pp. 281297,2017

[42]Lee, M. C., "Factors influencing the adoption of internet banking: An integration of TAM and TPB with perceived risk and perceived benefit", Electronic commerce research and applications, Vol. 8, No. 3, pp. 130-141, 2009

[43] Çelik, H., "Influence of social norms, perceived playfulness and online shopping anxiety on customers' adoption of online retail shopping: An empirical study in the Turkish context", International Journal of Retail \& Distribution Management, Vol. 39, No. 6, pp. 390-413, 2011

[44]Rose, S., \& Samouel, PP., "Internal psychological versus external market-driven determinants of the amount of consumer information search amongst online shoppers.", Journal of Marketing Management Vol. 25, No. 1-2, pp. 171-190, 2009

[45] Chiu, C. M., Chang, C. C., Cheng, H. L., \& Fang, Y. H., "Determinants of customer repurchase intention in online shopping", Online information review, Vol. 33, No. 4, pp. 761-784, 2009

[46] Mitra, K., Reiss, M. C., \& Capella, L. M. An examination of perceived risk, information search and behavioral intentions in search, experience and credence services. Journal of Services Marketing, Vol. 13, No. 3, pp. 208-228, 1999

[47] U. Dholakia, "A motivational process model of product involvement and consumer risk perception", European Journal of Marketing, vol. 35, no. 1112, pp. 1340-1362, 2001.

[48] Gefen, D., Rao, V.S., Tractinsky, N., 2002. The conceptualization of trust, risk and their relationship in electronic commerce. The need for clarifications. In: Proceedings of the 36th Hawaii International Conference on System Sciences (HICSS 03), Hawaii, USA, 2003, pp. 192.

[49] Pappas, N. Marketing strategies, perceived risks, and consumer trust in online buying behaviour. Journal of Retailing and Consumer Services, Vol. 29, pp. 92103, 2016

[50] Cho, M., Bonn, M. A., \& Kang, S. Wine attributes, perceived risk and online wine repurchase intention: The cross-level interaction effects of website quality. International Journal of Hospitality Management, Vol. 43, pp. 108-120, 2014

[51] Tong, X. A cross-national investigation of an extended technology acceptance model in the online shopping context. International Journal of Retail \& Distribution Management, Vol. 38, No. 10, pp. 742-759, 2010

[52] Huang, L. C., Goh, Y. N., \& Mohaidin, Z. Factors influencing consumer intentions to avoid broiler chicken meat and products in Malaysia. International Food Research Journal, Vol. 21, No. 1, 2014

[53] Kwon, W. S., \& Noh, M. The influence of prior experience and age on mature consumers' perceptions and intentions of internet apparel shopping. Journal of Fashion Marketing and Management: An International Journal, Vol. 14, No. 3, pp. 335-349, 2010 
[54] Saw, S. L., Goh, Y. N., \& Isa, S. M. Exploring consumers' intention toward online hotel reservations: insights from Malaysia. Problems and Perspectives in Management, Vol. 13, No. 2, pp. 249-257, 2015

[55] Doolin, B., Dillon, S., Thompson, F., \& Corner, J. L. Perceived risk, the internet shopping experience and online purchasing behavior: A New Zealand perspective. Journal of Global Information Management, Vol. 13, No. 2, pp. 66-88, 2005

[56] Drennan, J., Sullivan, G., \& Previte, J. Privacy, risk perception, and expert online behavior: An exploratory study of household end users. Journal of Organizational and End User Computing, Vol. 18, No. 1, pp. 1-22, 2006

[57] Al Kailani, M., \& Kumar, R. Investigating uncertainty avoidance and perceived risk for impacting Internet buying: A study in three national cultures. international Journal of Business and Management, Vol. 6, No. 5, pp. 76, 2011

[58] Noh, J., \& Vogt, C. Modelling information use, image, and perceived risk with intentions to travel to East Asia. Current issues in tourism, Vol. 16, No. 5, pp. 455476, 2013

[59] Samadi, M., \& Yaghoob-Nejadi, A. A survey of the effect of consumers' perceived risk on purchase intention in e-shopping. Business Intelligence Journal, Vol. 2, No. 2, pp. 261-275, 2009

[60] Wang, J., Yang, Z., \& Brocato, E. D. An investigation into the antecedents of prepurchase online search. Information \& Management, Vol. 55, No. 3, pp. 285293, 2018

[61] D'Alessandro, S., Girardi, A., \& Tiangsoongnern, L. Perceived risk and trust as antecedents of online purchasing behavior in the USA gemstone industry. Asia Pacific Journal of Marketing and Logistics, Vol. 24, No. 3, pp. 433-460, 2012

[62] Andrews, L., \& Boyle, M. V. Consumers' accounts of perceived risk online and the influence of communication sources. Qualitative Market Research: An International Journal, Vol. 11, No. 1, pp. 59-75, 2008

[63] Schmidt, J. B., \& Spreng, R. A. A proposed model of external consumer information search. Journal of the academy of Marketing Science, Vol. 24, No. 3, pp. 246-256, 1996

[64] Srinivasan, N., \& Ratchford, B. T. An empirical test of a model of external search for automobiles. Journal of Consumer research, Vol. 18, No. 2, pp. 233-242, 1991

[65] Huseynov, F., \& Yıldırım, S. Ö. Internet users' attitudes toward business-toconsumer online shopping: A survey. Information Development, Vol. 32, No. 3, pp. 452-465, 2016

[66] Spillinger, A., \& Parush, A. The impact of testimonials on purchase intentions in a mock e-commerce web site. Journal of theoretical and applied electronic commerce research, Vol. 7, No. 1, pp. 51-63, 2012

[67] Shim, S., Eastlick, M. A., Lotz, S. L., \& Warrington, PP. An online prepurchase intentions model: the role of intention to search., Journal of retailing, Vol. 77, No. 3 , pp. 397-416, 2001

[68] Morrison, K. (2014.Nov.28). 81\% of shoppers conduct online research before buying. infographic,Available:http://www.adweek.com/digital/81 shopperscondu ct-online-research-making-purchaseinfographic.

[69] Lu, Y., Cao, Y., Wang, B., \& Yang, S. A study on factors that affect users' behavioral intention to transfer usage from the offline to the online channel. Computers in Human Behavior, Vol. 27, No. 1, pp. 355-364, 2011

[70] Topaloğlu, C. Consumer motivation and concern factors for online shopping in Turkey. Asian Academy of Management Journal, Vol. 17, No. 2, pp. 1-19, 2012 
[71] To, PP. L., Liao, C., \& Lin, T. H. Shopping motivations on Internet: A study based on utilitarian and hedonic value. Technovation, Vol. 27,No. 12, pp. 774-787, 2007

[72] Podsakoff, PP. M., MacKenzie, S. B., \& Podsakoff, N. PP. Sources of method bias in social science research and recommendations on how to control it. Annual review of psychology, Vol. 63, pp. 539-569, 2012

[73] J. Hair, J. Risher, M. Sarstedt and C. Ringle, "When to use and how to report the results of PLS-SEM", European Business Review, vol. 31, no. 1, pp. 2-24, 2019.

[74] Henseler, J., Ringle, C. M., \& Sarstedt, M. A new criterion for assessing discriminant validity in variance-based structural equation modeling. Journal of the academy of marketing science, Vol. 43, No. 1, pp. 115-135, 2015

[75] Kline, R. B. (2016). Principles and practice of structural equation modeling (4th ed.). New York: The Guilford Press.

[76] F. Hair Jr, J., Sarstedt, M., Hopkins, L., \& G. Kuppelwieser, V. Partial least squares structural equation modeling (PLS-SEM) An emerging tool in business research. European Business Review, Vol. 26, No. 2, pp. 106-121, 2014

[77] Hayes, A. F. Beyond Baron and Kenny: Statistical mediation analysis in the new millennium. Communication monographs, Vol. 76, No. 4, pp. 408-420, 2009

[78] Preacher, K. J., \& Hayes, A. F. Asymptotic and resampling strategies for assessing and comparing indirect effects in multiple mediator models. Behavior research methods, Vol. 40, No. 3, pp. 879-891, 2008

[79] Baron, R. M., \& Kenny, D. A. The moderator-mediator variable distinction in social psychological research: Conceptual, strategic, and statistical considerations. Journal of personality and social psychology, Vol. 51, No. 6, pp. 1173, 1986

[80] Moon, M. A., Farooq, A., \& Abbasi, G. A. 3g/4g mobile network band wagon in Pakistan: a mixed method inquiry into consumer adoption attitude. University of Wah Journal of Management Sciences, Vol. 17, 2018

[81] Abbasi, G. A., Yow, B. C., \& Goh, Y. N. Does the milk powder scare matter? A survey examining Penang's consumer purchase intention with attitude as the mediator. International Food Research Journal, Vol. 27, No. 2, 2020.

[82] Abbasi, G. A., Goh, Y. N., \& Ariffin, S. K. Stimulating online buying behaviour among millennials in Pakistan: a conceptual model and research propositions. Journal of Entrepreneurship, Business and Economics, Vol. 7, No. 2, pp. 189-219, 2019.

[90] Iranmanesh, M., Senali, M. G., Ghobakhloo, M., Nikbin, D., \& Abbasi, G. A. (2021). Customer behaviour towards halal food: a systematic review and agenda for future research. Journal of Islamic Marketing. 